2) Decalmer S, O'Driscoll BR. Oxygen: friend or foe in peri-operative care? Anaesthesia 2013;68:8-12.

3) Ventilation with lower tidal volumes as compared with traditional tidal volumes for acute lung injury and the acute respiratory distress syndrome. The Acute Respiratory Distress Syndrome Network. N Engl J Med 2000;342:1301-8.

4) 金井理一郎, 鵜澤康二, 森山 潔, 他. パルスオキシメー ターの低酸素血症検出に関する信頼性の検討。日集中医誌 2014;21:175-6

5) 瀬尾勝弘. $\mathrm{SpO}_{2}$ のアラーム設定レベル $: \mathrm{SpO}_{2}$ と $\mathrm{SaO}_{2}$ の乘 離. 日集中医誌 2014;21:130-1.

6) Suzuki S, Eastwood GM, Glassford NJ, et al. Conservative oxygen therapy in mechanically ventilated patients: a pilot before-and-after trial. Crit Care Med 2014;42: 1414-22.

7) Australian New Zealand Clinical Trials Registry. Feasibility and safety of conservative versus liberal oxygen targets in the mechanically ventilated patients. CLOSE I study. Available from: https://www.anzctr.org. $\underline{\mathrm{au} / \text { Trial/Registration/TrialReview.aspx? } \mathrm{id}=364185}$

受付日 2014 年 7 月 3 日 採択日 2014 年 7 月 3 日
鈴木 聡*1, 森松 博史*2

$* 1$ 岡山大学病院集中治療部

*2 岡山大学大学院医歯薬学総合研究科麻酔 - 蘇生学分野

（ ₹ 700-8558 岡山県岡山市北区鹿田町 2-5-1）

\section{Therapeutic targets for oxygen therapy in critical illness}

To the Editor: Satoshi Suzuki ${ }^{*}{ }^{1}$, Hiroshi Morimatsu*2

${ }^{*} 1$ Department of Intensive Care, Okayama University Hospital

* 2 Department of Anesthesiology and Resuscitology, Okayama University Graduate School of Medicine.

(2-5-1 Shikata-cho, Kita-ku, Okayama, Okayama 700-8558, Japan)

J Jpn Soc Intensive Care Med 2015;22:156-7.

\title{
人工呼吸器関連肺炎に対する抗菌薬吸入療法
}

\section{はじめに}

人工呼吸器関連肺炎 (ventilator-associated pneumonia, VAP) は集中治療領域に打ける最も重要 な院内感染症であり, 死亡率上昇 11,2$)$, ICU 滞在日数や 入院日数延長 ${ }^{2}$, 医療費増加 ${ }^{2)}$ にも寄与している。近年, 薬剤耐性菌の増加 ${ }^{3)}$ によりその治療は難しくなってい る。特に既存の静注抗菌薬による標準的な治療が困難 な多剂耐性緑膿菌や多剂耐性Acinetobacter baumanniiをはじめとする耐性グラム陰性桿菌の治療 戦略は, 新規抗菌薬開発が進んでいないことを背景に, 非常に限られたオプションしか残されていない4)。こ のため, 今日では一般的に使用されない古い薬剤の再 評価 (例：コリスチン, ホスホマイシンなど), 多剤併 用療法5), pharmacokinetics/pharmacodynamics $(\mathrm{PK} / \mathrm{PD})$ を駆使した投与方法 (例： $\beta$ ラクタム系抗菌 薬の持続投与) 6),7)などが行われているが, 特にVAP
に対しては抗菌薬の吸入療法も有望な治療戦略として 期待されている ${ }^{8)}$ 。吸入療法は, 経静脈的投与に比心゙ 肺胞での抗菌薬濃度の上昇と早いクリアランスが期待 でき, 治療効果の向上, 副作用の軽減, 薬剂耐性のリ スク軽減などの理論的メリットがある。歴史的には, 囊胞性線維症に扔ける緑膿菌の慢性気道感染に対する 治療として確立している戦略であるが9),10), VAPの治 療戦略としては経験も科学的検証も不十分である。本 稿ではVAPに対する抗菌薬吸入療法の臨床エビデン スおよび問題点について解説する。

\section{これまでに吸入療法が研究されてきた抗菌薬}

これまでにコリスチン, アミノグリコシド系抗菌薬, $\beta$ ラクタム系抗菌薬, ホスホマイシンなどの吸入療法 の臨床研究が行われている。

1) コリスチン

吸入療法への応用が最も困難な抗菌薬と考えられて 
いる。不活型プロドラックとして投与され緩徐に加水 分解を受けることで誘導されるが, その過程で有害性 が懸念される物質を放出する。また，その作用機序は 界面活性剂としてグラム陰性桿菌の細胞膜を直接傷害 することによるが, 高濃度の場合, 哺乳類の細胞にも 作用し気道や肺胞の細胞傷害を惹起する可能性が指摘 されており11)，適切な投与量については未解明であ る。

\section{2) アミノグリコシド系抗菌薬}

優れた抗グラム陰性桿菌作用を有し, 囊胞性線維症 における緑膿菌およびその他のグラム陰性桿菌による 慢性気道感染に対し用いられてきた。その腎毒性, 神 経毒性のため静注での使用は敬遠される傾向にある が, 吸入療法ではそのリスクは大幅に軽減される。ま た，その濃度依存性の殺菌作用は，高い気道内濃度の 達成と速やかなクリアランスを特徵とする吸入療法に 適していると考えられる。主な欠点は喀痰中のムチン による拮抗作用 8 )で, 気道内で効力を発揮するには最 小発育阻止濃度 (minimal inhibitory concentration, $\mathrm{MIC})$ の 25 倍以上の濃度が必要とされる ${ }^{12) 。 し た か ゙ っ ~}$ て, 近年の高度耐性菌に対しては理論的にも吸入アミ ノグリコシド系抗菌薬単剤での治療は難しいと考えら れている。

\section{3） $\beta$ ラクタム系抗菌薬}

殺菌作用は time above MICに依存するため, クリ アランスの速い吸入療法には理論上向かない。実際, セフタジジムが検証された小規模 randomized controlled trial (RCT) 13)では 3 時間ごとの投与が行わ れており，実践的ではないと考えられる。カルバペネ ム系抗菌薬ではドリペネムによる肺臓炎が報告され 14) 臨床研究は進んでいない。

4) ホスホマイシン

細胞壁の合成を阻害し, グラム陰性菌, 陽性菌の両 方に活性を有するユニークなクラスの抗菌薬である。 変異, 耐性獲得が容易で単剂療法は推奨されない。ア ミノグリコシド系抗菌薬との併用でそのリスクは大幅 に滅弱することが知られている15)。アミカシンとの 併用療法は近年, VAP患者に対する第 1 相試験16)で評 価されている。

\section{抗菌薬吸入療法の技術的問題点}

吸入製剤の要件として, 防腐剂無添加, 非高浸透圧, 中性に近い $\mathrm{pH}$ ，適切なイオン組成などが挙げられる。 静注用製郕はこれらの要件を満たさず，そのまま吸入 投与することはできない8)。したがって, 同じ抗菌薬 であっても, 静注用製剂とは別に吸入用製剂の開発が
必要となる。また, 病巣に抗菌薬を到達させるため, 特殊なデリバリーシステムの開発も重要な課題であ る。多くのネブライザでは粒子径が大きすぎ，抗菌薬 の大部分が気管チューブや気道に付着してしまう。ま た, 回路中の水分は粒子径を膨張させ, 抗菌薬の到達 距離をさらに短縮させる。抗菌薬を肺胞まで到達させ るためには極めて小さな粒子にする必要があり，特別 なデバイスが開発され臨床試験が行われている12),16)。 通常のネブライザを用いて静注用抗菌薬を吸入させる ことは理論的にも有効性が期待できず, 人工呼吸器の 呼気弁や呼気流量計の作動に障害を及ぼす可能性もあ る。

\section{これまでの臨床研究}

VAPに対する抗菌薬吸入療法に関する近年の RCT をTable 1にまとめた。いずれも小規模で, 生命予後 や人工呼吸器期間など臨床的に意味のあるアウトカム で有効性を示した研究はない。抗菌薬の選択やデリバ リーシステムの問題が解決されておらず, 臨床プラク ティスに影響を与えるインパクトをもった臨床研究が 行われる段階に至っていないのが現状である。

\section{結 論}

薬剤耐性菌によるVAPの治療戦略として抗菌薬の 吸入療法が期待され臨床研究が進められている。静注 用製剂とは異なる吸入専用製剂および専用の吸入デバ イスの開発が課題となっており, 大規模臨床研究には 至っていないのが現状である。

本稿のすべての著者には規定されたCOIはない。

\section{文 献}

1) Bekaert M, Timsit JF, Vansteelandt S, et al; Outcomerea Study Group. Attributable mortality of ventilatorassociated pneumonia: a reappraisal using causal analysis. Am J Respir Crit Care Med 2011;184:1133-9.

2) Kollef MH, Hamilton CW, Ernst FR. Economic impact of ventilator-associated pneumonia in a large matched cohort. Infect Control Hosp Epidemiol 2012;33:250-6.

3) Fridkin SK. Increasing prevalence of antimicrobial resistance in intensive care units. Crit Care Med 2001;29 (4 Suppl):N64-8

4) Boucher HW, Talbot GH, Bradley JS, et al. Bad bugs, no drugs: no ESKAPE! An update from the Infectious Diseases Society of America. Clin Infect Dis 2009;48:1-12.

5) Araoka H, Baba M, Takagi S, et al. Monobactam and aminoglycoside combination therapy against metallo-betalactamase-producing multidrug-resistant Pseudomonas aeruginosa screened using a 'break-point checkerboard plate'. Scand J Infect Dis 2010;42:231-3.

6) Tamma PD, Putcha N, Suh YD, et al. Does prolonged 


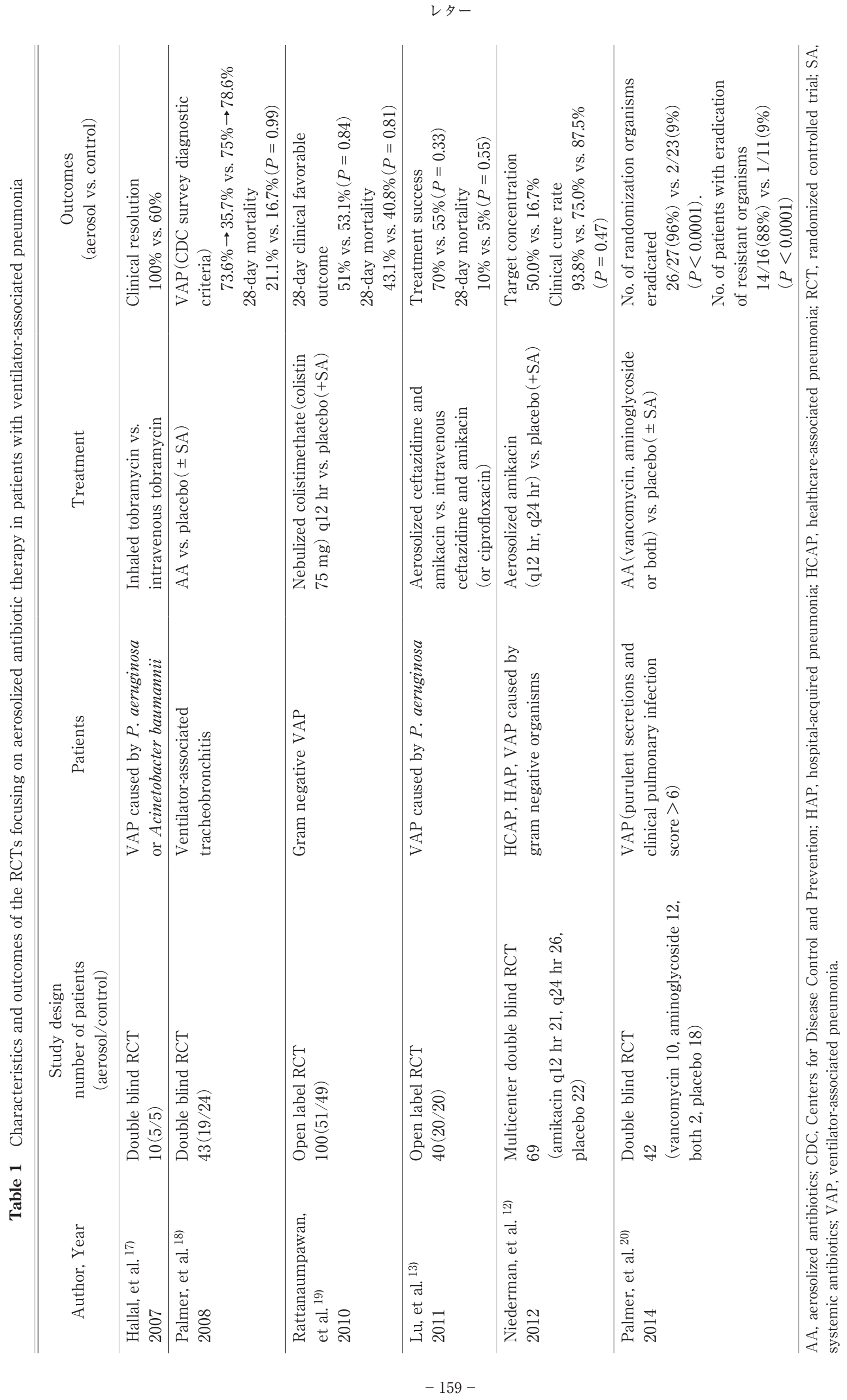


$\beta$-lactam infusions improve clinical outcomes compared to intermittent infusions? A meta-analysis and systematic review of randomized, controlled trials. BMC Infect Dis 2011;11:181.

7) Falagas ME, Tansarli GS, Ikawa K, et al. Clinical outcomes with extended or continuous versus short-term intravenous infusion of carbapenems and piperacillin/ tazobactam: a systematic review and meta-analysis. Clin Infect Dis 2013;56:272-82.

8) Kollef $\mathrm{MH}$, Hamilton $\mathrm{CW}$, Montgomery AB. Aerosolized antibiotics: do they add to the treatment of pneumonia? Curr Opin Infect Dis 2013;26:538-44.

9) Ramsey BW, Pepe MS, Quan JM, et al. Intermittent administration of inhaled tobramycin in patients with cystic fibrosis. Cystic Fibrosis Inhaled Tobramycin Study Group. N Engl J Med 1999;340:23-30.

10) McCoy KS, Quittner AL, Oermann CM, et al. Inhaled aztreonam lysine for chronic airway Pseudomonas aeruginosa in cystic fibrosis. Am J Respir Crit Care Med 2008;178:921-8.

11) McCoy KS. Compounded colistimethate as possible cause of fatal acute respiratory distress syndrome. N Engl J Med 2007;357:2310-1.

12) Niederman MS, Chastre J, Corkery K, et al. BAY41-6551 achieves bactericidal tracheal aspirate amikacin concentrations in mechanically ventilated patients with Gram-negative pneumonia. Intensive Care Med 2012;38: 263-71.

13) Lu Q, Yang J, Liu Z, et al; Nebulized Antibiotics Study Group. Nebulized ceftazidime and amikacin in ventilatorassociated pneumonia caused by Pseudomonas aeruginosa. Am J Respir Crit Care Med 2011;184:106-15.

14) Hilas O, Ezzo DC, Jodlowski TZ. Doripenem (doribax), a new carbapenem antibacterial agent. P T 2008;33:134-80.

15) MacLeod DL, Barker LM, Sutherland JL, et al. Antibacterial activities of a fosfomycin/tobramycin combination: a novel inhaled antibiotic for bronchiectasis. J Antimicrob Chemother 2009;64:829-36.

16) Montgomery AB, Vallance S, Abuan T, et al. A Randomized Double-Blind Placebo-Controlled Dose-Escalation Phase 1 Study of Aerosolized Amikacin and Fosfomycin Delivered via the PARI Investigational eFlow(®) Inline Nebulizer System in Mechanically
Ventilated Patients. J Aerosol Med Pulm Drug Deliv 2014;27:441-8.

17) Hallal A, Cohn SM, Namias N, et al. Aerosolized tobramycin in the treatment of ventilator-associated pneumonia: a pilot study. Surg Infect (Larchmt) 2007;8: 73-82.

18) Palmer LB, Smaldone GC, Chen JJ, et al. Aerosolized antibiotics and ventilator-associated tracheobronchitis in the intensive care unit. Crit Care Med 2008;36:2008-13.

19) Rattanaumpawan $P$, Lorsutthitham J, Ungprasert $P$, et al. Randomized controlled trial of nebulized colistimethate sodium as adjunctive therapy of ventilator-associated pneumonia caused by Gram-negative bacteria. J Antimicrob Chemother 2010;65:2645-9.

20) Palmer LB, Smaldone GC. Reduction of bacterial resistance with inhaled antibiotics in the intensive care unit Am J Respir Crit Care Med 2014;189:1225-33.

受付日 2014 年 10 月 16 日 採択日 2014 年 11 月 17 日

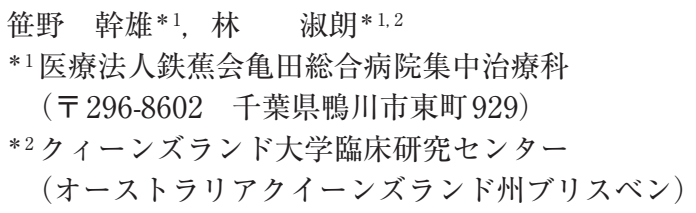

Aerosolized antimicrobial therapy in the treatment of ventilator-associated pneumonia

To the Editor: Mikio Sasano*1, Yoshiro Hayashi*1,2

${ }^{*} 1$ Department of Intensive Care Medicine, Kameda Medical Center (929 Higashi-cho, Kamogawa, Chiba 296-8602, Japan)

${ }^{*} 2$ UQ Centre for Clinical Research, The University of Queensland (Herston, QLD 4029, Australia)

J Jpn Soc Intensive Care Med 2015;22:157-60. 